

\title{
Pai de todos, pai de ninguém: modelos de paternidade no período abolicionista
}

\section{Pai de todos, nobody's father: paternity models in the abolitionist period}

\section{Cláudia Laitano ${ }^{1}$}

Resumo: Este trabalho busca levantar as representações literárias das relações de pais e filhos negros ou mestiços ao longo do século 19, em especial depois da proibição do tráfico de escravos (1850). A partir da leitura de textos de autores como José de Alencar, Joaquim Manuel de Macedo, Bernardo Guimarães, Machado de Assis e Aluísio Azevedo, o trabalho propõe quatro categorias com que se pretende abarcar as visões mais comuns da paternidade mestiça em textos literários produzidos no Brasil no período abolicionista.

Palavras-chave: pai; literatura brasileira; escravidão; negro.

Abstract: This work seeks to analyze the literary representations of the relations of black or mixed-race parents and children throughout the 19th century, especially after the prohibition of the slave trade (1850). The paper is based on the works by authors such as José de Alencar, Joaquim Manuel de Macedo, Bernardo Guimarães, Machado de Assis and Aluísio Azevedo and proposes four categories that encompass the most common views of fatherhood in literary texts produced in Brazil in the abolitionist period.

Keywords: father; brazilian literature; slavery; black man.

Nos reinos da antiga Costa dos Escravos, na África Ocidental, de onde partiu boa parte dos escravizados que chegaram ao Brasil entre os séculos 17 e 19, a figura do pai e do avô eram essenciais na estruturação das famílias, na organização social e política das diferentes linhagens e nas práticas religiosas, baseadas, via de regra, no respeito pelos mais velhos e na relação mística com os ancestrais. No livro $O$ rei, o pai e a morte, em que estuda as crenças religiosas da região onde se situa hoje a República do Benim, Luis Nicolau Parés destaca a importância da descendência patrilinear no sistema social que vigorava na época em que o tráfico negreiro se instalou com mais força, a partir do final do século 17.

$\mathrm{Na}$ sequência que vai do pai genitor (daá mejito), passando pelo pai social (daá hennugan), até o pai espiritual (tohuiyo), há uma gradação crescente em idade, em autoridade, e na extensão do grupo sobre o qual se exerce essa autoridade. Aliás, há

\footnotetext{
1 Jornalista (1992), especialista em Economia da Cultura pelo Programa de Pós-graduação em Economia da UFRGS (2007) e mestranda em Literatura Brasileira na mesma universidade. Colunista do jornal Zero Hora, de Porto Alegre, desde 2004.
} 


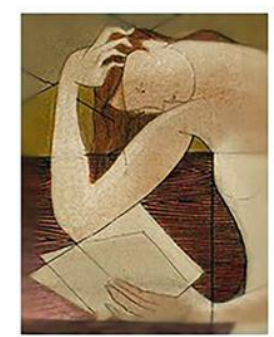

também uma progressão em ancestralidade, indo do mais humano ao mais divinizado. Embora se possa argumentar que a recorrência da noção de paternidade é resultado de um uso apenas linguístico, devemos reconhecer o caráter estruturante desse idioma do parentesco na organização e na prática social. (PARÉS, 2016, p. 61)

Do outro lado da costa do Atlântico, os cativos que sobreviviam à devastadora travessia dos navios negreiros encontravam no Brasil uma outra espécie de sociedade profundamente patriarcal, fundada sobre valores europeus adaptados à realidade dos trópicos. Nesse novo ambiente, estruturado social e economicamente sobre as bases da escravidão, homens brancos exerciam um poder absoluto sobre a família e a escravaria, enquanto homens negros escravizados eram privados não apenas da liberdade, mas também do direito de exercer a paternidade e de cultuar seus antepassados. Para os escravizados, a paternidade era reduzida ao sentido meramente biológico da função. Era esperado de homens fortes e saudáveis que procriassem com as mulheres escravizadas, gerando assim novos homens-mercadorias, mas não que se apegassem aos seus filhos ou transmitissem a eles qualquer tipo de valor ou tradição. O pai do escravo, via de regra, não tinha nome ou linhagem - a não ser, é claro, quando se tratava de um homem livre que havia se relacionado e tido filhos com uma escrava.

Esse apagamento da figura do pai escravizado (ou recém-liberto) de filhos escravizados (ou recém-libertos) se reflete, como não poderia deixar de ser, na literatura brasileira, principalmente a partir do momento em que negros e mestiços passam a figurar como tema e personagens na ficção. Em contos, peças e romances do século 19, são muitos os filhos mestiços de pais brancos - sejam eles ricos ou pobres. Esses pais podem vir a ser cruéis, indiferentes ou eventualmente até generosos com seus filhos, reconhecendo e batizando sua prole bastarda. Temos também algumas mães escravizadas, em geral divididas nas usuais categorias femininas de abnegadas ou lascivas, conforme o tipo de relação que mantiveram com os pais de seus filhos e como essa relação se desenvolveu. O pai negro, por sua vez, é uma figura rara na literatura do período.

Uma paternidade meramente simbólica, estabelecida entre um "preto-velho" doméstico e seus senhores mais próximos, parece a única acessível para esses personagens que não cultuam antepassados e não deixam descendentes. Um "pai preto" 




como esse aparece, por exemplo, no romance Iaiá Garcia, de Machado de Assis, na figura de Raimundo, "um tipo de africano submisso e dedicado", que mesmo depois de ganhar a liberdade prefere continuar servindo seu senhor, a quem amava "como se fora seu filho" (ASSIS, 1959, p. 9). Por diferentes motivos, a começar pelo fato de o Romantismo brasileiro ter escolhido o índio, e não o escravizado, como personagem mítico nacional a ser idealizado, não existe o equivalente negro de uma obra como $I$ Juca-Pirama (1851) - poema indianista de Gonçalves Dias que gira em torno da relação entre um jovem guerreiro tupi e seu pai, em uma narrativa marcada por valores como honra, respeito e responsabilidade com relação aos mais velhos.

Nesse contexto em que as linhagens de negros e mestiços são afetadas diretamente pelas limitações impostas pela escravidão, a começar pela dificuldade de estabelecer um núcleo familiar estável, diferentes modelos de relacionamentos entre pais e filhos serão retratados na literatura brasileira, expondo, propositadamente ou não, as marcas da escravidão. Neste trabalho, esses modelos são divididos em quatro grandes grupos: Pai Patrão (filhos mestiços de pais brancos), Crias da Casa (escravos criados “como filhos"), Pai desconhecido (pai livre que rejeita o filho mestiço) e Pai mitológico (figura paterna que se afasta do registro realista). As histórias aqui examinadas cobrem um intervalo que vai de 1860 a 1890 - não por acaso o período em que personagens negros e mestiços passaram a ocupar algum espaço na ficção brasileira. Brookshaw (1983) associa esse movimento de assimilação do negro à literatura ao fim do tráfico de escravos, que passou a ser cumprido, a contragosto, em 1850, depois de décadas de pressão da Inglaterra.

Depois de 1850, a abolição do tráfico de escravos forçou os escritores brasileiros a voltarem sua atenção aos escravos, e em particular ao tratamento que recebiam, dado que o prolongamento da escravidão dependia consideravelmente de como os negros eram tratados. Assim, a literatura de 1850 em diante demonstra, em grande parte, preocupações pelo escravo, aparecendo o primeiro romance em folhetim com essa temática em 1856, intitulado $O$ Comendador, de Pinheiro Guimarães. (BROOKSHAW, 1983, p.28)

Produzida, com raras exceções, por autores brancos, a literatura de viés abolicionista do período não estará livre de estereótipos (BROOKSHAW). Alguns deles (o mulato passional e rebelde, a mulata lasciva e amoral) envolvem traços que 


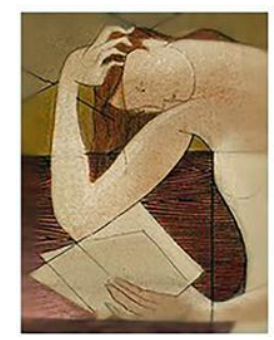

inviabilizam ou fragilizam a possibilidade de um núcleo familiar e, por consequência, a presença de um pai. Não é de se espantar, portanto, que a figura paterna de negros e mestiços seja tão invisível ou evanescente. Por outro lado, está claro que as peculiaridades do sistema escravista são determinantes nesse esvaziamento da figura paterna. Goes e Florentino (1999), analisando inventários post-mortem de proprietários rurais falecidos nas áreas rurais do Rio de Janeiro entre 1789 e 1830, demonstram que a regra, entre escravos, era não ter nem pai nem mãe reconhecidos: "Antes mesmo de completarem um ano de idade, uma entre cada 10 crianças já não possuía nem pai nem mãe anotados nos inventários. Aos cinco anos, metade parecia ser completamente órfã. Aos 11, oito a cada 10". (GOES; FLORENTINO, 1999, p. 180). Também a alforria, em muitos casos, fazia desaparecer dos registros oficiais os vínculos familiares.

\section{Pai patrão}

O primeiro autor negro a descrever sua dolorosa relação com o pai branco não o fez por meio de um texto literário. Narrada em uma carta enviada ao advogado Lúcio de Mendonça, datada de 25 de julho de 1880, a história da relação do poeta e abolicionista Luiz Gama (1830-1882) com o pai é tão ou mais dramática do que qualquer ficção que tenha sido escrita sobre o tema no período da escravidão. Trata-se de um dos raros documentos escritos por um ex-escravo, filho de uma mulher africana, a respeito das suas origens familiares.

\footnotetext{
Meu pai não ouso afirmar que fosse branco, porque tais afirmativas, neste país, constituem grave perigo perante a verdade, no que concerne à melindrosa presunção das cores humanas: era fidalgo e pertencia a uma das principais famílias da Bahía, de origem portuguesa. Devo poupar à sua infeliz memória uma injúria dolorosa, e o faço ocultando seu nome. Ele foi rico e, nesse tempo, muito extremoso para mim: criou-me em seus braços. Foi revolucionário em 1837. Era apaixonado pela diversão da pesca e da caça: muito apreciador de bons cavalos, jogava bem as armas, e muito melhor de baralho, amava as súcias e os divertimentos: esbanjou uma boa herança, obtida de uma tia em 1836, e reduzido à pobreza extrema, a 10 de novembro de 1840 , em companhia de Luiz Cândido Quintela, seu amigo inseparável e hospedeiro, que vivia de proventos de uma casa de tavolagem na cidade da Baía, estabelecida em um sobrado de quina, ao largo da praça, vendeu-me, como seu escravo, a bordo do patacho Saraiva. (SANTOS, 2010, p. 22)
}

Ainda que singular como testemunho pessoal, o pungente relato autobiográfico de Luiz Gama está longe de ser excepcional como circunstância histórica. O conjunto 




formado por um pai branco, uma mãe negra ou mulata e um filho mestiço, ciente ou não sua própria origem, pode ser considerado hegemônico na literatura brasileira do século 19 que tocou o tema da mestiçagem. Não por acaso. É sabido que a miscigenação étnica desempenhou um papel fundamental na formação do Brasil. A escravidão apenas tornaria mais "doméstica" uma prática que havia se iniciado bem antes, quando os primeiros portugueses encontraram as primeiras índias nas costas do país. A miscigenação tornou-se prática corrente entre senhores e escravas: “Acostumados a ver nos escravos bens pessoais, os senhores, mesmo que pobres, estendiam seu senhorio à esfera sexual, de maneira que não seria exagero dizer que a escravidão não raro implicava a possibilidade de concubinato" (VAINFAS, 1997, p. 234).

Uma das primeiras obras a colocar um personagem negro no papel de protagonista, a peça de teatro Mãe (1860), de José de Alencar, dará contornos quase românticos à ligação da escrava com o homem branco que se tornaria pai do seu filho. A peça narra a história de Joana, mãe de Jorge, cujo pai, Soares, morreu logo depois que o menino foi batizado. Para proteger o filho da mácula da escravidão, Joana decide criar Jorge como se fosse apenas sua ama de leite, sem que o menino saiba que ela é sua verdadeira mãe, o que só será revelado a ele no final da peça. A trama pouco se detém na figura de Soares, mas sabemos que era um homem de poucas posses, talvez mais velho, que se relacionou com uma Joana ainda quase adolescente quando ela pertencia a outra pessoa. Quando soube que Joana esperava um filho seu, Soares comprou-a de seu antigo dono, tornando-se seu novo senhor: "Ele me queria tanto bem! Deu por mim tudo quanto tinha... Dois contos de réis!" (ALENCAR, s. d, p. 34). Soares reconheceu o filho e o batizou, mas não tornou Joana sua esposa e nem assumiu publicamente o fato de que ela era a mãe de seu filho. De certa forma, a trama rocambolesca do homem que batiza um menino sozinho, como se fosse filho de ninguém, inverte o arranjo convencional. Temos aqui um pai solteiro e uma mãe invisível - ou invisibilizada.

Em registro naturalista, Aluísio Azevedo constrói um triângulo familiar sobre as mesmas bases no romance $O$ mulato (1881). Raimundo, como Jorge, ignora suas origens. Educado na Europa e criado por um padrinho, o jovem retorna ao Brasil disposto a esclarecer o mistério sobre o seu passado. Quando decide pedir a mão da 




prima Ana Rosa em casamento, descobre através do tio Manuel que o casamento seria impossível pelas convenções da sociedade maranhense da época: apesar dos olhos azuis e da pele clara, Raimundo havia nascido escravo. Seu pai, José Pedro da Silva, foi morto por um inimigo quando ele era criança. A mãe ainda estava viva, mas havia perdido a razão e vagava como andarilha.

Repete-se aqui a fórmula do homem branco que engravida uma escrava, mas não renega o filho: "Depois de vários abortos, Domingas deu à luz um filho de José da Silva. Chamou-se o vigário da freguesia e, no ato do batismo da criança, esta, como a mãe, receberam solenemente a carta de alforria" (AZEVEDO, 2010, p. 40). O arranjo mais ou menos estável que unia José Pedro, Domingas e a criança, a quem o pai cercava de cuidados, colapsa quando entra em cena dona Quitéria, a mulher branca com quem José Pedro decide se casar legalmente. Quitéria logo percebe a ligação do marido com a escrava e seu filho pequeno, e ordena que o menino seja mandado embora: "Seu negreiro! gritava ela ao marido, fula de raiva. Você pensa que lhe deixarei criar, em minha companhia, os filhos que você tem das negras? Era só também o que faltava!" (AZEVEDO, 2010, p. 41). Para proteger Raimundo do ódio de Quitéria, José Pedro leva o menino para morar com o irmão, Manuel, a quem pede que encaminhe o filho para os estudos na Europa se ele vier a morrer, o que acaba acontecendo pouco tempo depois.

José Pedro dá carinho e zela pelo futuro do filho, a quem concede, além do nome, a liberdade, mas nesse precário arranjo familiar, formado por um senhor e a escrava que um dia havia lhe salvado sua vida, a mãe negra é relegada à posição de coadjuvante descartável, entregue à própria sorte. Herói clivado, Raimundo herdará da mãe a mácula da escravidão, que eventualmente causará sua ruína, e do pai o dinheiro originado, ironicamente, do tráfico de escravos.

Em um livro eivado de estereótipos negativos nas descrições do comportamento, da moral e da aparência de negros e mestiços, Joaquim Manuel de Macedo colocará o ódio, a dissolução de costumes e o permanente desejo de vingança dos escravos como eixo central das três narrativas curtas reunidas no livro As vítimas algozes: quadros da escravidão (1869). Para Macedo, a escravidão avilta a sociedade menos pelo sofrimento que causa aos negros do que pelos riscos que a convivência com escravos pode 


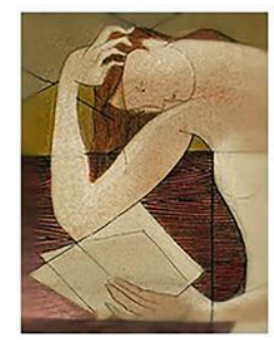

representar para o caráter dos brancos. Em Pai-Raiol, o feiticeiro, é a mulher (algoz) que seduz o homem (vítima), invertendo a relação de poder entre escrava e senhor. Sob o comando do feiticeiro Pai-Raiol, que não era pai de ninguém mas impunha seu poder sobre os outros escravos por meio da maldade e o conhecimento dos segredos da magia, a negra Esméria trai a confiança de sua senhora branca, Teresa, seduzindo o dono da casa, Paulo Borges, e levando à ruína toda a família.

\begin{abstract}
Honrado e escrupuloso em seus negócios, Paulo Borges dava pouca importância à severidade dos costumes e reputando a castidade virtude somente imperiosa para senhoras, julgava-se irrepreensível porque não se sujeitava a ligação alguma que não fosse passageira. A sua moralidade era a de muitos: era um véu escondendo opróbrios, ou fraquezas indignas. Paulo Borges procurou e possuiu facilmente Esméria. $\mathrm{O}$ demônio da lascívia deu poder à crioula. Possesso da depravação, Paulo Borges, o senhor, amou fisicamente Esméria, a escrava. A calculada extravagância de um dia tornou-se o vício, primeiro de muitos, depois de quase todos os dias. O senhor, o velho senhor ficou escravo de sua escrava. (MACEDO, 1988, p. 113)
\end{abstract}

O poder de Esméria sobre o amante é tão grande que ela acaba ocupando o lugar de Teresa como dona da casa. Depois de se livrar da rival, Esméria descobre que está esperando um filho, que pode ou não ser de Paulo Borges. Fica aliviada ao ver que a criança é branca e começa então a tramar a morte dos filhos de Teresa, seus rivais na disputa de uma futura herança. Com a morte dos irmãos, seu filho passa a ser o único herdeiro de Paulo Borges - ganhando "do desgraçado que era seu pai e senhor" também a liberdade. A carta de alforria que entregou à Esméria e seu filho, porém, seria apenas provisória. Desmascaradas as artimanhas de Pai-Raiol e Esméria para dominá-lo e destruir sua família, Paulo Borges é incapaz de devolver a vida à mulher e aos filhos mais velhos, mas pode punir e renegar a criança que havia tido com a escrava. Torna-se o algoz do próprio filho, em quem reconhece não apenas a corrupção moral da escrava que o enfeitiçou, mas a sua própria depravação.

Que importa o horror da morte do Pai-Raiol?... Que importa o castigo justíssimo de Esméria, que perante a autoridade pública acabara por confessar todos os seus crimes? Que importa que Paulo Borges rasgasse o testamento que fizera e que em assanhos de seródia vingança e em desvarios de remorsos, desprezasse, e arredasse de sua casa o filho que tivera da perversa crioula, punindo assim no inocente a própria depravação?... (MACEDO, 1988, página 165) 


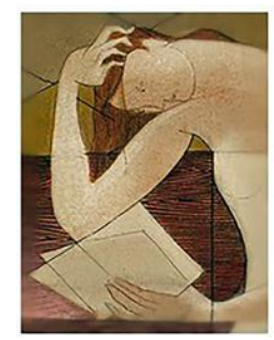

\section{Crias da casa}

Além dos senhores que tinham filhos com suas escravas, reconhecendo ou não a paternidade, a escravidão engendrou um outro tipo de arranjo familiar que colocava escravos domésticos a meio caminho entre a liberdade e o cativeiro, assim como entre o afeto familiar genuíno e a relação de poder e posse. Esses "agregados" eram crianças filhas de escravas que, por um motivo ou outro, acabavam sendo criadas junto às famílias da casa grande, recebendo algum carinho e boa educação, mas carregando para sempre a marca de sua origem na senzala - mesmo quando sua aparência não denunciasse imediatamente sua ascendência racial.

No conto Mariana, publicado no Jornal das Famílias em 1871, Machado de Assis usa a expressão "cria da casa" para definir o personagem principal, uma escrava "criada como filha da casa" e tratada "como se fosse pessoa livre".

Chamava-se Mariana, continuou ele alguns minutos depois, e era uma gentil mulatinha nascida e criada como filha da casa, e recebendo de minha mãe os mesmos afagos que ela dispensava às outras filhas. Não se sentava à mesa, nem vinha à sala em ocasião de visitas, eis a diferença; no mais era como se fosse pessoa livre, e até minhas irmãs tinham certa afeição fraternal. Mariana possuía a inteligência da sua situação, e não abusava dos cuidados com que era tratada. Compreendia bem que na situação em que se achava só lhe restava pagar com muito reconhecimento a bondade de sua senhora. A sua educação não fora tão completa como a de minhas irmãs; contudo, Mariana sabia mais do que outras mulheres em igual caso. Além dos trabalhos de agulha que lhe foram ensinados com extremo zelo, aprendera a ler e a escrever. Quando chegou aos 15 anos teve desejo de saber francês, e minha irmã mais moça lho ensinou com tanta paciência e felicidade, que Mariana em pouco tempo ficou sabendo tanto como ela. (ASSIS, 2020)

A "inteligência da sua situação", ou seja, a capacidade da escrava de saber seu lugar e não exigir mais do que lhe é concedido pela família que a protege, não impede Mariana de entregar-se à fantasia romântica que selará seu destino. Apaixonada pelo "nhônhô" Macedo, que narra a história com frieza e certa vaidade, Mariana acaba cometendo suicídio. Escolhe para si mesma um desfecho tristemente comum entre os escravos. Macedo deixa no ar a ideia de que a escolha poderia ter sido outra, mais convencional: tornar-se sua amante.

Confesso, entretanto, que, apesar de não competir de modo nenhum os sentimentos de Mariana, entrei a olhar para ela com outros olhos. A rapariga tornara-se interessante para mim, e qualquer que seja a condição de uma mulher, há sempre dentro de nós um fundo de vaidade que se lisonjeia com a afeição que ela nos vote. Além disto, surgiu em meu espírito uma idéia que a razão pode condenar, mas que nossos costumes aceitam 


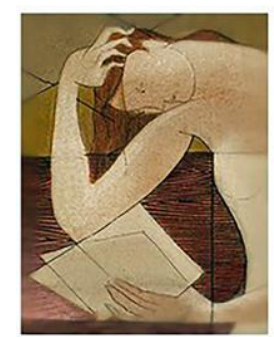

perfeitamente. Mariana encarregara-se de provar que estava acima das veleidades. (ASSIS, 2020)

Mariana não se sentia tão escrava a ponto de aceitar viver uma relação ilegítima com o homem por quem nutria fantasias românticas, nem era livre o suficiente para escolher sozinha o próprio destino. Era uma criatura cindida. Sem passado e sem genealogia, uma vez que sua origem e a identidade dos seus pais são apagadas em nome da família a quem ela pertence. Sem futuro, porque nunca poderia encaixar-se completamente em nenhum dos dois mundos dos quais fazia parte.

O personagem do conto de Machado de Assis tem muitos pontos em comum com aquela que viria a ser a mais famosa "cria da casa" da literatura brasileira. A escrava Isaura (1875), de Bernardo Guimarães, narra a história de outra moça educada com esmero e tratada "como filha". Isaura fala francês, toca piano e, mais importante, sabe seu lugar. Lançado em meio à pressão crescente pelo fim da escravidão, que seria abolida apenas na década de seguinte, o romance de Bernardo Guimarães tinha como objetivo denunciar a crueldade do sistema que trata pessoas como mercadorias. Talvez convencido de que seus argumentos seriam mais convincentes se os leitores se identificassem com o personagem, Guimarães concebe uma improvável escrava cuja tez "é como o marfim do teclado" (GUIMARÃES, 1979, p. 9).

Talvez por ser branca, Isaura, ao contrário de Mariana, tem direito a uma genealogia. Sabemos que sua mãe era "uma linda mulata" - mucama favorita da dona da casa e objeto de desejo do senhor "libidinoso e sem escrúpulos" a quem pertence. Seu pai, Miguel, era um "fiel feitor" branco. Com a morte da mãe e a expulsão do pai da propriedade, Isaura é criada como filha pela senhora da casa. Sua tranquilidade acaba quando sua protetora morre, e Leôncio, herdeiro dos escravos e do caráter do pai, decide que Isaura deve cumprir os esperados deveres de mulher-propriedade.

Dentro da perspectiva da paternidade que examinamos no presente trabalho, Isaura é uma escrava especialmente afortunada. Miguel exerce a paternidade de maneira ativa e corajosa. Com apoio da dona da casa, continua mantendo contato com a filha mesmo depois de cair em desgraça e ser expulso. Ao contrário de tantos outros personagens mestiços que ignoram sua genealogia ou mesmo as condições de seu 




nascimento, Isaura cresce sabendo quem é, de onde veio e quem são seus pais. No começo do romance, vamos encontrá-la ao piano, entoando uma cantiga que evoca sua origem: "Desd'o berço respirando / Os ares da escravidão, / Como sempre lançada / Em terra de maldição / A vida passo chorando / Minha triste condição" (GUIMARÃES, 1979, p. 8).

Antes de a história se encaminhar para seu desfecho romântico, com a derrocada de Leôncio e a liberdade de Isaura sendo enfiam comprada pelo dinheiro de Álvaro, Miguel é o grande herói masculino do romance - um pai-herói, na medida de suas possibilidades de homem livre sem recursos: "Enquanto o sangue me girar nestas veias, enquanto me restar o mais pequenino recurso, hei de lançar mão dele para te salvar" (GUIMARÃES, 1979, p. 81).

Quando percebe que a filha está em perigo, Miguel apela à proteção das leis para impedir que Isaura seja vítima das violências e sevícias de seu senhor. Convencido a desistir da Justiça, que seria de pouca valia em casos como aquele, o feitor consegue poupar o valor necessário para comprar a liberdade da filha, mas isso também não dá certo. Como último recurso para livrar Isaura da obsessão de Leôncio, Miguel foge com ela para outro Estado e muda de identidade. Pela filha ilegítima que teve com uma escrava, o ex-feitor, ironicamente, transforma-se ele mesmo em fugitivo e fora da lei. A dedicação abnegada de Miguel à filha, ou seja, o retrato dessa paternidade virtuosa moldada segundo ideais românticos que pouco tinham em comum com a realidade de escravos de verdade, é apenas mais um dos aspectos inverossímeis no retrato da escrava branca que toca piano e fala francês.

O protagonista de Simeão o crioulo, primeira das três histórias de As vítimas algozes: quadros da escravidão (1869), de Joaquim Manuel de Macedo, é outro personagem cindido entre a liberdade e a escravidão. Enquanto Mariana e Isaura são “crias da casa" que crescem "sabendo seu lugar", Simeão é o escravo revoltado que trai a confiança da família que o acolheu, causando sua ruína. Filho de uma escrava com um homem que nem sequer é mencionado na história, Simeão é amado "como filho adotivo" e conservado como escravo. 


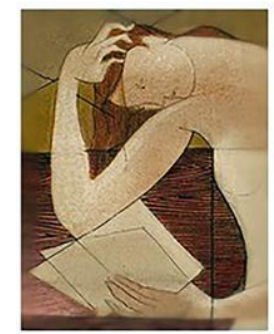

Habituado à impunidade garantida pela afeição, ousa muito e abusa ainda mais, como predileto da família, e escravo, portanto infeccionado por todos os vícios e ferozes impulsos da madre-fera escravidão, insolente e malcriado, nem perfeitamente livre nem absolutamente escravo, bom juiz odiento, pois que conhece as duas condições, e da melhor é bastardo, e da pior legítimo filho. (MACEDO, 1988, p. 22)

Dormindo no quarto dos senhores até os oito anos e criado sem limites, como uma criança livre e mimada, Simeão demora a tomar consciência da condição de escravo. Quando finalmente se descobre "coisa e não homem”, sua reação é de revolta, sentimento que aos poucos se transformará em ódio e desejo de vingança. Simeão estabelece então uma duplicidade de comportamento, quase como uma espécie de contraponto às duplicidades nem filho/nem escravo e nem livre/nem cativo a que fora exposto desde o berço. Para usar as duas categorias de estereótipos de personagens negros desenvolvidas por Brookshaw em Raça \& cor na literatura brasileira (BROOKSHAW, 1983), Simeão, em casa, encena a performance do "escravo fiel", enquanto na rua, em contato com negros rebeldes, começa a se transformar no "escravo demônio" que causará o final trágico da família que o criou e dele mesmo. Carregada de estereótipos na descrição de personagens negros ("pervertido crioulo", "mãos devassas" "lábios torpes") que não deixam em dúvida o racismo que move o abolicionismo de Macedo, a história de Simeão, como a de Isaura e Mariana, coloca em evidência a precariedade da condição das "crias da casa", condenadas a habitar um não lugar entre a casa grande e a senzala.

\section{Pai desconhecido}

No meio urbano, fora da órbita de senhores que têm filhos com suas escravas e das senhoras que se apegam, ou maltratam, seus criados domésticos, a paternidade se constitui (ou não se constitui) de outras formas. Em $O$ cortiço (1890), romance naturalista lançado poucos meses depois da Abolição, entram em cena as crianças negras ou mestiças criadas sem pai, não porque o ambiente da escravidão dificultava a formação de laços familiares permanentes, mas porque as relações que geraram essas crianças eram inconsequentes e fugazes. 


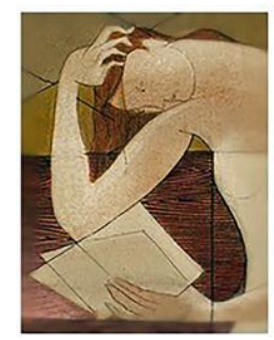

No primeiro plano do romance de Aluísio Azevedo, temos a figura da mulata Rita Baiana, que seduz um homem casado, o português Jerônimo, fazendo com que ele largue a mulher e a filha para manter um romance com ela. Ligações amorosas que se fazem e se desfazem ao sabor da ocasião, deixando para trás crianças em situações familiares precárias, porém, estão longe de ser a exceção no cortiço onde os moradores multiplicam-se "como larvas no esterco" (AZEVEDO, 2016, p. 27). Da lavadeira portuguesa "Machona", por exemplo, não se sabe se é viúva ou desquitada, mas os filhos "não se pareciam uns com os outros" (p. 43).

A subtrama em que se desenvolve melhor o modelo do pai branco que não assume o filho mestiço é a que envolve a gravidez da menina mulata Florinda. Filha da lavadeira Marciana, Florinda aparece "de barriga” e ninguém sabe quem é o pai. Quando a menina finalmente revela que o homem que a engravidou é Domingos, caixeiro na venda de João Romão, dono do cortiço, Marciana exige que ele tome conta de Florinda e da criança que ela espera. Talvez por se tratar de uma adolescente, a moral reinante no cortiço é de que o caixeiro deve cumprir com suas obrigações, mas a ideia de casar com Florinda ou assumir o filho nem lhe passa pela cabeça. Na primeira oportunidade, Domingos foge, de uma só vez, da paternidade, do casamento e da fúria da mãe ofendida. Mãe e filha, como último recurso, ainda tentam recorrer à Justiça, mas descobrem que a lei, se existe, não foi feita para pessoas como elas e a criança mestiça que está para nascer:

Marciana foi com a pequena à procura do subdelegado e voltou aborrecida, porque lhe disseram que nada se poderia fazer enquanto não aparecesse o delinquente. Mãe e filha passaram todo esse sábado na rua, numa roda-viva, da secretaria e estações de polícia para o escritório de advogados que, um por um, lhes perguntavam de quanto dispunham para gastar com o processo, despachando-as sem mais considerações, logo que se inteiravam da escassez de recursos de ambas as partes. (AZEVEDO, 2016, p. 136)

\section{Pai mitológico}

O conto Virginius, de Machado de Assis, publicado originalmente no Jornal das Famílias, em 1864, apresenta uma curiosa exceção na forma como a paternidade negra ou mestiça é retratada na ficção brasileira do século 19. Julião, descrito como "trigueiro" e pai da "mulatinha mais formosa daquelas dez léguas em redor", é um 


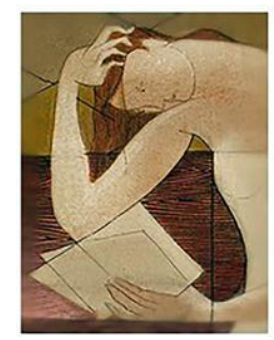

homem livre, talvez ex-escravizado, que vive como agregado do grande senhor de terras da região - um benfeitor conhecido como Pai de Todos, alcunha que não deixa dúvidas a respeito da força do patriarcado no Brasil de meados do século 19.

Julião não apenas cria, com zelo, a filha Elisa, como chega a formar com ela e a mulher, já morta no momento em que se passa a ação do conto, um núcleo familiar estável e coeso. Como qualquer pai ciente de suas obrigações, mais ainda aqueles que criam seus filhos em situação social e econômica precária, Julião preocupa-se com o futuro da filha e seu sustento depois de sua morte, escapando ao estereótipo do pai negro ausente ou indiferente que era a norma na literatura do período.

Laborioso por necessidade e por gosto, Julião bem depressa viu frutificar o seu trabalho. Ainda assim não descansava. Queria, quando morresse, deixar um pecúlio à filha. Morrer sem deixá-la amparada era o sombrio receio que o perseguia. (ASSIS, 2020)

Pai de Todos também tem um filho, Carlos, que vai estudar fora e volta para casa alguns anos depois, mas a paternidade onipotente, de ecos míticos, expressa por seu apelido é acima de tudo simbólica, uma vez que ele acumula as funções de proprietário (de terras e de escravos), juiz, provedor e referência moral da região. O bem-estar daqueles que orbitam em torno de Pai de Todos está associado à sua disposição natural para fazer o bem, traço não necessariamente transmitido à geração seguinte, como o desenrolar do conto irá demonstrar. A Justiça propriamente dita só se faz necessária diante das "grandes causas", como um assassinato cometido dentro de um mesmo estrato social. De resto, todos os impasses e conflitos são decididos pelo patriarca. Os negros e mestiços a quem concede a liberdade de tempos em tempos têm tão poucas opções viáveis fora da esfera de influência do seu protetor que, como empregados ou agregados, preferem permanecer em posição subserviente a exercerem plenamente sua liberdade longe dali.

Ao contrário do pai, descrito como um homem bom e generoso com seus escravos, Carlos é violento e indiferente ao trabalho na fazenda. Seus únicos interesses são a caça e Elisa, sua companheira de brincadeiras na infância, a quem agora vê como uma presa a ser subjugada. Diante dos avanços cada vez mais insistentes de Carlos, Julião não tem outra saída a não ser apelar para que o rapaz se compadeça de Elisa, uma 


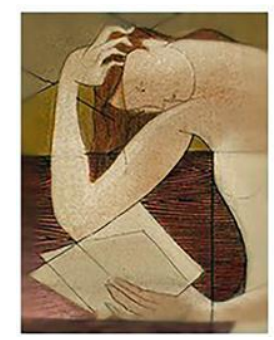

vez que não há Justiça à qual ele possa recorrer sem ofender a relação com seu protetor. Carlos, porém, não se compadece. Ignora a condescendência do pai com escravos e agregados e mesmo a condição de liberdade de que Julião e Elisa desfrutam. Seu modelo de comportamento não é o do pai, mas o do "patrão demônio" (parafraseando a categoria proposta por Brookshaw para os escravos), que considera apenas natural violentar e subjugar suas escravas, obedecendo à tradicional lógica da posse sexual que regula a relação dos senhores com mulheres negras ou mestiças. Pode-se imaginar que nenhuma tragédia teria acontecido se Elisa fosse uma escrava ou se se encaixasse no estereótipo da mulata sensual que seduz ou se entrega ao patrão. Em outras palavras, se não tivesse um pai que a protegesse, mas apenas um dono que pudesse dispor do seu corpo. Elisa, porém, tem pai, e esse pai zela pela honra e pelo futuro da filha como se não existisse outra atitude admissível. Para proteger sua liberdade e sua honra, Julião vai apelar ao recurso extremo e desesperado de tornar-se o assassino da própria filha.

Com a morte de Elisa e a prisão de Julião, Carlos é castigado pelo pai, e não pela Justiça, mas tanto Pai de Todos quanto Julião sentem-se pacificados com o castigo escolhido para o "patrão demônio". Pagar o advogado e acolher Julião em sua casa, depois de cumprida a pena pelo assassinato determinada pela Justiça, é a compensação estabelecida no tribunal paralelo comandado por Pai de Todos. E os dois pais terminam a história sem seus filhos, unidos na infelicidade: "Aqueles dois pais, que assistiram ao funeral de suas esperanças, acham-se ligados intimamente pelos laços do infortúnio". (ASSIS, 2020)

Se imaginarmos Julião e Elisa como mestiços livres ou recém-libertos, o conto de Machado torna-se quase uma ilustração daquilo que Slenes (2011) tentará demonstrar no livro $\mathrm{Na}$ senzala, uma flor, baseado em novos estudos historiográficos sobre a família escrava realizados em Campinas e em outras regiões do Sudeste: os arranjos familiares estáveis entre escravizados e ex-escravizados eram muito mais comuns do que a historiografia clássica (e poderíamos acrescentar a literatura brasileira do século 19) nos leva a crer.

Durante todo o século 19, o complexo de grande lavoura em Campinas (centrado primeiro no açúcar, depois no café) criou sérios empecilhos para a formação de grupos de parentesco, nucleares e extensos, entre os escravos, mas não a ponto de deixar os 


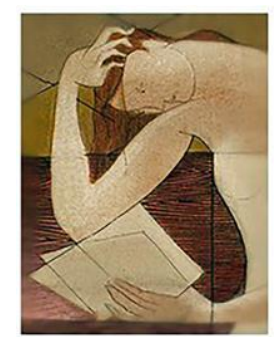

cativos destituídos de instituições e normas familiares. Tanto nas plantations de café quanto nas de açúcar - ou, mais amplamente, nas propriedades com mais de dez cativos -, os escravos conseguiram casar-se, manter unidas suas famílias conjugais e até construir redes de parentesco extensas, com mais frequência do que os historiadores haviam pensado. (SLENES, 2011, p. 56)

Para Slenes, a visão hegemônica da vida íntima na senzala é aquela que apresenta quadros de promiscuidade sexual, uniões conjugais de ocasião e filhos que crescem sem a presença dos pais. Esse tipo de representação teria começado no século 19 e se estendido por boa parte do século 20. Em A Integração do negro na sociedade de classes (1965), o sociólogo Florestan Fernandes afirma que a fragilidade dos laços de parentesco era uma estratégia usada pelos senhores de escravos para solapar iniciativas de união ou solidariedade que poderiam enfraquecer seu poder. Em As religiões africanas no Brasil (1971), o antropólogo francês Roger Bastide mostra como os cativos no Brasil eram criados não apenas sem linhagem, mas também sem pai. Slenes matiza essa visão, demonstrando que famílias de escravos bem estruturadas também existiam e que algumas tradições africanas, como a aceitação da poliginia e a centralidade da mãe na vida afetiva dos filhos, possibilitaram algum tipo de adaptação às condições de resto precárias do escravismo. Os autores brasileiros que se debruçaram sobre o tema da escravidão no século 19 acabaram refletindo essa visão muitas vezes esquemática e estereotipada das relações familiares entre escravos, retratando diversas formas de paternidade dentro de um mesmo modelo: a virtual ausência do pai negro.

O núcleo familiar formado por Julião, sua mulher e Elisa pode ter sido em algum momento estável e completo, mas essa estabilidade mostra-se insuficiente para que toquem sua vida de maneira tranquila como trabalhadores livres. Duas tragédias atravessam o caminho dessa família. Uma delas é a que é narrada no conto: mesmo livre, Elisa, como mulata e agregada, não tem direito de negar seu corpo ao senhor de escravos Carlos. A Justiça oficial é uma abstração, e o favor dos senhores de bom coração não é suficiente. A outra é apenas sugerida rapidamente no conto, mas não explicitada: "Pio, no fim de certo tempo, deu a Julião um sítio que ficava pouco distante da fazenda, para lá fora morar Julião com uma filha menor, cuja mãe morrera em consequência dos acontecimentos que levaram Julião a recorrer à proteção do 




fazendeiro" (capítulo II). Fica a sugestão de que também a mãe de Elisa havia sido vítima de um tipo de violência parecido e que lhe havia custado a vida.

Atilio Bergamini Junior, na tese de doutorado "Criação literária no outono do escravismo - Machado de Assis" (2013), insere Virginius no ambiente de "modernização" da década de 1860, na esteira da proibição do tráfico de escravos, determinada em 1850. Para o autor, o jovem Machado de Assis articularia nesse conto a utopia da abolição da escravidão (determinada, no âmbito privado, por patriarcas esclarecidos como Pai de Todos) e as alternativas reais de adaptação e assimilação dos ex-escravizados à sociedade (contra a vontade de senhores apegados à velha ordem, como Carlos).

Julião está entre dois polos, o dos acontecimentos que ocorrem por toda parte e o da decisão do escravista ético. Entre uma e outra potências, ele tem possibilidade de fazer algumas escolhas desesperadas, escolhas que, no entanto, o redirigem à tragédia. Em outros termos: nem por tomar a - sob o ponto de vista do conto - boa decisão de procurar a proteção de Pio, Julião e Elisa fogem ao destino trágico do agregado (exescravo?) no escravismo: o corpo - e a classe social - de Elisa estão em constante risco de sofrer violência e exclusão. (BERGAMINI JUNIOR, 2013, p.100)

Ao criar um personagem mestiço que exerce a paternidade até o limite do desespero e do autossacrifício, assim como uma jovem mulata que ousa recusar seu corpo ao senhor de escravos, Machado revela e ao mesmo tempo esconde os "pais de ninguém" gerados pela escravidão. No lugar do pai ausente ou desconhecido, Julião é ciente de seu papel e de suas responsabilidades com a pequena família que formou. No lugar da mulata sedutora ou submissa, Elisa é a menina casta que prefere morrer a perder a inocência e abdicar da honra. Em sua negação quase absoluta dos estereótipos vigentes, pai e filha parecem, em alguma medida, irreais, como figuras exageradamente rígidas usadas com o objetivo de revelar algo que escapa ao mero valor de face da história.

Aproximando o drama de Julião à tragédia romana de Virginius, sua filha Virgínia e o decênviro Ápio Cláudio, o escritor ressalta ainda mais o caráter mitológico dos personagens, sem deixar de expressar um forte sentido moralizante de condenação do caráter desumano da escravidão. Em seu aspecto simbólico, o núcleo familiar que Julião e Elisa mantiveram até o desfecho trágico mostra o caminho que o Brasil poderia 


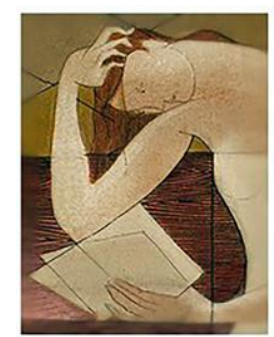

vir a tomar, mesmo que pela via paternalista simbolizada por Pai de Todos, se o embate de forças entre o senhor esclarecido e justo e o "senhor demônio" tivesse sido vencido pelo primeiro.

\section{Referências}

ALENCAR, José de. Mãe. Biblioteca Virtual de Literatura: s. d. Disponível em: http://www.dominiopublico.gov.br/download/texto/bi000161.pdf. Acesso em: 25 jan. 2020.

ASSIS, Machado de. Mariana. Disponível em: https://machadodeassis.ufsc.br/obras/contos/avulsos/CONTO,\%20Mariana,\%201871.ht m. Acesso em: 6 fev. 2020.

ASSIS, Machado de. Virginius. Disponível em: https://machadodeassis.ufsc.br/obras/contos/avulsos/CONTO,\%20Virginius, \%201864.h tm. Acesso em: 6 fev. 2020.

AZEVEDO, Aluísio. O cortiço. São Paulo: Penguin Classics Companhia das Letras, 2016.

AZEVEDO, Aluísio. O mulato. São Paulo: Saraiva, 2010.

BERGAMINI JUNIOR, Atilio. Criação literária no outono do escravismo - Machado de Assis. 2013, 303p. Tese (Doutorado em Literatura Brasileira) - Instituto de Letras, Universidade Federal do Rio Grande do Sul. Porto Alegre, 2013.

BROOKSHAW, David. Raça \& cor na literatura brasileira. Porto Alegre: Mercado Aberto, 1983.

GUIMARÃES, Bernardo. A escrava Isaura. São Paulo: Ática, 1979.

GOES, José Roberto; FLORENTINO, Manolo. Crianças escravas, crianças de escravos. In: DEL PRIORE, Mary (org). História das crianças no Brasil. São Paulo: Contexto, 1999. p. 177-191.

MACEDO, Joaquim Manoel de. As vítimas algozes: quadros da escravidão. Rio de Janeiro: BestBolso, 2012.

PARÉS, Luis Nicolau. O rei, o pai e a morte: a religião vodum na antiga Costa dos Escravos na África Ocidental. São Paulo: Companhia das Letras, 2016.

SANTOS, Luiz Carlos. Luiz Gama. São Paulo: Selo Negro Edições, 2010. 

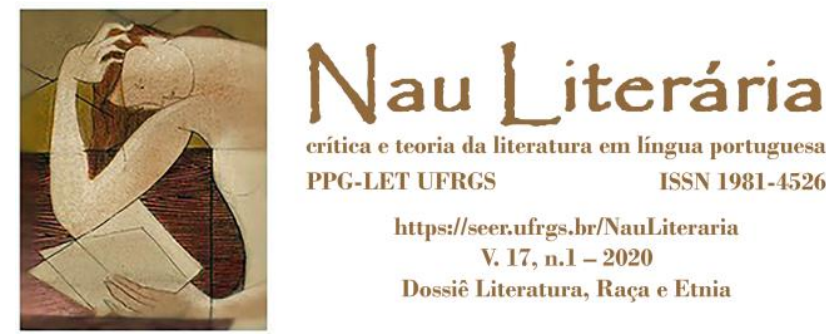

SLENES, Robert W. Na senzala, uma flor - Esperanças e recordações na formação da família escrava - Brasil Sudeste, século XIX. Campinas: Editora da Unicamp, 2011.

VAINFAS, Ronaldo. Moralidades brasílicas. In: NOVAIS, Fernando A, SOUZA, Laura de Mello (Org). História da vida privada no Brasil, volume 1. São Paulo: Companhia das Letras, 1997. 